\title{
Modelling tourism employment in China
}

\author{
XIANG WEI
}

Beijing International Studies University, National School of Development, Peking University, No 1 Southern Ding Zhuang Road, Chao Yang District of Beijing, China. E-mail:weixiang@bisu.edu.cn.

\section{HAILIN QU}

School of Hotel and Restaurant Administration, Oklaboma State University, Stillwater, OK 74078, USA, and School of Business, Sun Yat-Sen University, China. E-mail: h.qu@okstate.edu. (Corresponding author.)

\section{EMILY MA}

Department of Tourism, Leisure, Hotel and Sport Management, Griffith University, Nathan Campus, Queensland 4111, Australia. Email:emily.ma@griffith.edu.au.

This study develops and tests a tourism employment model with 17year time series data in China. The model reveals that tourism employment does not always grow in accordance with the tourism economy. The results indicate that tourism employment in China is driven mainly by the development of tourism-related industries. The results also show that technological progress has a slight negative effect on tourism employment in China.

Keywords: tourism employment; production function; growth model; VAR model; China

China's economy has developed rapidly in the past three decades, with an average gross domestic product (GDP) growth rate of over $8 \%$ per annum. The rapid growth of GDP, however, has not created corresponding employment growth since the 1990s (Chang, 2005). China's population increased dramatically from 0.975 billion in 1979 to 1.334 billion in 2009, an increase of $37 \%$ (CHINA POPIN, 2009). In 2002, the surplus labour supply in rural areas reached 150 million (Rong, 2003). In addition, following the state-owned enterprise (SOE) reform (started in the 1990s), another 14 million of surplus labour force were released (Rong, 2003). Researchers have noticed the 'creative 
destruction' effect of technology on employment growth: as technology advances, a smaller labour force is needed (Schumpeter, 1934; Saint-Paul, 1992). Technology advancement in China has been impressive over the past 30 years. The astonishingly rapid development and application of technology has exerted pressure on China's macro economy, especially its employment. China is now facing a greater challenge in employment than ever before.

Tourism has been recognized as an industry that can effectively absorb surplus labourers (Falk and Broner, 1980). Since 1978, tourism in China has developed rapidly and has become the largest sector in the service industry (China National Tourism Administration, 2007). The World Tourism Organization (UNWTO) has forecast that China would become the number one tourism destination in the world by 2020 (UNWTO, 2001). Evidence indicates a bright future for China's tourism industry.

Historically, tourism has been identified as an industry that can generate foreign exchange. Only recently have the government and academics started to recognize the possibility of using tourism to resolve the challenge of China's unemployment because tourism is a labour intensive industry (Ireland, 1993; Ross, 1992).

This study investigates the tourism employment growth pattern in China and addresses two questions. Does the rapid growth of China's tourism industry positively lead to a corresponding growth of tourism employment? What factors determine the growth of tourism employment in China? In this situation, a model describing the growth pattern of tourism employment in China would be very useful in predicting the needs of labour forces in the tourism industry.

\section{Literature review}

\section{Tourism employment}

In 2000, the Tourism Division of Asia-Pacific Economic Cooperation (APEC) and the World Travel and Tourism Council (WTTC) jointly issued 'The Economic Impact of Travel and Tourism Development in the APEC Region 2000' (WTTC, 2000). In accordance with the System of National Accounts (SNA), this report used the Tourism Satellite Account (TSA) for the first time. TSA defines the tourism employment system as comprising four parts. The first part is direct tourism employment, which includes service positions where workers directly provide services to tourists. Examples of the sepositions include airline companies, hotels, taxis and car rental companies, restaurants, stores and recreation places. The second part is indirect tourism employment which provides job positions supporting the tourism industry, such as airline food suppliers, laundry services, wholesalers and finance service providers. The third part is direct employment in the tourism suppliers' industries. These include government agencies, manufacturing product suppliers, the construction industry and the tourism souvenirs production industry. The fourth part is the indirect employment in the tourism supplier's industries. These industries provide production materials to the suppliers of the tourism industry.

This paper focuses on the direct employment in the tourism industry (that is, the first part of tourism employment defined by TSA). Tourism employment in this study was measured by the number of employees or positions in the 
tourism industry at a specific time. The measurement of tourism employment in this study is consistent with the method employed in the Annual Tourism Statistics system administered by the China National Tourism Administration (CNTA).

\section{Growth of tourism economy}

The growth of the tourism economy (also referred as tourism GDP) is measured by the added value in the tourism industry. Tourism added value refers to the ultimate output of tourism in a certain period (usually a year), which includes the added value produced by the tourism and hospitality industry and the transferred value from fixed assets ( $\mathrm{Li}$ and $\mathrm{Li}, 1999)$. Tourism GDP includes direct added value, indirect added value and total added value. This study employed the method provided by the TSA to measure Tourism GDP. Literature on tourism economic growth is dominated by econometric studies testing the validity of the tourism-led growth (TLG) and generally emphasizes the positive role of tourism demand on economic growth (Balaguer and Cantavella-Jorda, 2002; Fayissa et al, 2008, 2009; Oh, 2005).

\section{Relationship between tourism development and tourism employment}

Generally speaking, the development of the tourism economy has a stimulating effect on tourism employment (Holloway, 1994; Akkemik, 2012). However, tourism development does not always lead to increased tourism employment. First, employment usually refers to full-time jobs. If we do not count the increase in temporary or part-time jobs, we come to different conclusions regarding tourism employment. For instance, in the 1980s many jobs were created in China's tourism industry. However, most of the jobs were temporary or part-time positions. Second, the growth of tourism employment is subject to the seasonal fluctuation of the tourism economy (Ashworth and Thomas, 1999; Joppe, 2012). Third, the expansion of high-end tourism consumption (such as luxury hotels) creates an imbalance between the development of the tourism economy and tourism employment (Brenner and Aguilar, 2002). Fourth, in developing countries, the imbalance between inbound and outbound tourism also limits the growth of tourism employment (Strizzi and Meis, 2001).

Many researchers have investigated the relationship between tourism economy and tourism employment. Reime and Hawkins (1979) described tourism development stages based on industry growth, employment volume, impact factors and psychological effect. Nwanna (1996) studied tourism employment in the context of macroeconomic environment. McClary (2002) tested the influence of sudden events on tourism employment and found that sudden events usually decrease the level of tourism employment. However, two obvious flaws can be found in these studies. First, the models presented or developed in these studies lack precise mathematic function, thus limiting their applicability. Second, there is no systematic analysis in the momentum growth of tourism employment.

\section{Factors determining tourism employment growth}

Although many researchers have established general employment models, few researchers have attempted to model the employment growth patterns in 
the tourism industry (Pissarides, 1990). Among the very few studies on tourism employment, Chetri et al (2008) examined Tourism Related Employment (TRE) through the application of spatial econometric techniques. However, this study focused only on geographical and environmental factors that influence tourism employment, while overlooking the relationship between tourism economy and tourism employment. Chetri et al (2008) further argued that additional factors need to be considered in modelling tourism employment. Considering China's economic development stage and the current situation of tourism industry, the following factors were chosen as determinants of China's tourism employment.

\section{The development level of technology}

Office automation, management information systems and database-driven marketing are examples of the major manifestations of technology application and advancement in the tourism industry (Gamble, 1988; Poon, 1993). All of these technological innovations rely on fixed capital formation. While fixed capital formation is not only associated with a company's technology application level, its change over time can be influenced by the advancement of technology. The 'creative destruction' effect of technology on employment growth has been well noted in the literature. 'Creative destruction' means that the more advanced the technology, the less labour force is needed in an economy (Schumpeter, 1934; Saint-Paul, 1992). The development level of technology in the tourism industry should be considered as one of the factors determining tourism employment in China.

\section{Tourism employment multiplier}

The tourism employment multiplier refers to the increased number of full-time jobs brought by a unit of consumption in tourism (including direct, indirect and induced consumption) (Pomeroy et al, 1988). The tourism employment multiplier can be calculated by the following steps: (i) determine the employment volume needed for a unit of output in the tourism related industry; (ii) compute the increased output in tourism related industries caused by tourism consumption; (iii) calculate the employment volume provided by the increase of tourism consumption in tourism related industries; and (iv) divide the employment volume as calculated in step 3 by the consumption volume of the tourism-directly influenced industries to get the employment multiplier.

According to labour economics theory, the complementary effect of employment among industries or the employment multiplier effect can facilitate economic growth and increase employment (Aghion and Howitt, 1994). Therefore, the tourism employment multiplier should also be considered as one of the factors determining tourism employment (Wanhill, 1988).

\section{Environmental pressure caused by tourism production and consumption}

Although there is still no standard measurement for the environmental pressure created by the tourism industry, most researchers propose that environmental pressure created by tourism is positively correlated to tourist arrivals (Simpson, 1999; Huybers and Bennett, 2000). Furthermore, tourist arrivals can influence tourism employment (Johnson and Thomas, 1990; Sinclair, 1998). Tourist 
arrivals can better serve as a proxy figure to represent the environment pressure created by the tourism industry. Therefore, tourist arrivals should be considered as a factor that will influence tourism employment growth.

\section{Theoretical model}

Pissarides (1990) proposed a model on the relationship between the tourism economy and environmental pressure in the context of neoclassic economics. Using his model, a tourism production function can be expressed as follows:

$$
y_{t}=A_{t}(z x)^{\alpha},
$$

where $y_{t}$ represents the per capita outcome of the tourism economy at time $t$, and $A_{t}$ is the technical parameter of tourism; $x$ is the amount of intermediate products (Romer, 1986) in tourism production; $z$ represents the pressure that the tourism production and consumption put on the natural environment; and $\alpha$ is the output elasticity of intermediate product.

Pissarides's model appears to be more appropriate applied in our study for the following reasons: (i) this model was originally designed for service industry in which tourism belongs to; (ii) the model adopts a dynamic approach which makes it more realistic to describe tourism employment seasonality; and, (iii) the model takes the factor of environmental pressure into account in addition to other common factors.

After considering the additional factors that may influence tourism employment growth in China, we proposed the following hypothesized model mainly based on Pissarides's (1990) work. The proposed model includes three independent variables that determine tourism employment growth, including Technology, Tourism Employment Multiplier (Correlation between Tourism and its Related Industries), and Environmental Pressure. Taking its origination from general views and theories in labor economics, the proposed model is written as follows (see Appendix 1 for the proof of this theoretical model):

$$
w^{*}=m(1, v)\left[\ln M P_{x}^{M}-\frac{(\alpha+\rho) \ln p_{\varepsilon}+\alpha g_{t}}{\ln A_{0}^{\rho} \zeta^{\alpha}}\right] / g,
$$

where $w^{*}$ is tourism 'natural employment rate', namely employment rate consistent with the natural unemployment rate of tourism industry, The 'natural' rate of unemployment is defined as the rate of unemployment that exists when the labor market is in equilibrium and there is pressure from neither rising inflation rates nor falling inflation rates (Hall and Lilien, 1979); $\zeta$ represents the environmental pressure per capita generated by production and consumption in tourism; $m(1, v)$ represents the time a worker takes to look for a new position where 1 represents the total number of the labour force looking for jobs, $v$ represents the number of vacant positions, and evidence shows $m$ is an increasing function of $v$ (Pissarides, 1990); $M P_{x}^{M}$ is the marginal output of intermediate products at the highest price; $g$ is the equilibrium growth rate of the output of intermediate product in tourism, and $g_{t}$ is the exogenous growth rate of 
technology in tourism; $\alpha$ and $\rho$ are parameters of the production function; $\rho_{\varepsilon}$ is the price of intermediate products in tourism; $A_{0}$ is technology level of tourism at the beginning when $t=0$.

Three propositions are generated from above model:

Proposition 1: When the technology level of tourism is low and the tourism employment multiplier effect is weak, increased environmental pressure will enhance tourism employment (see Appendix 2 for the deduction of Proposition 1).

Proposition 2: Technological advancement in tourism will facilitate tourism employment by providing new career opportunities, and will reduce the effect of 'creative destruction' on tourism (see Appendix 2 for the deduction of Proposition 2).

Proposition 3: Tourism economy growth and tourism employment growth are positively related when a complementary relationship between tourism and its related industries is present (see Aghion and Howitt (1994) for the similar deduction of Proposition 3).

To summarize, the tourism economy can positively affect tourism employment in three ways. First, the growth of tourism economy can enhance tourism technology, which leads to more career opportunities. The created jobs can help to reduce the effect of 'creative destruction.' This is regarded as a 'sustainable' effect on tourism employment growth. Second, a strong complementary relationship for employment between tourism and its related industries can stimulate tourism demand. However, realization of increasing tourism demand in this regard is largely determined by the inter-dependability between tourism and its related industries. As a result, the tourism economy and tourism employment could grow simultaneously. Third, environmental pressure can extend the scale of the tourism industry, which leads to increased tourism employment. This could be used as a short-term strategy. However, it is not sustainable in nature, considering the potential negative impact of tourism development on environment.

\section{Methodology}

\section{Data}

A 17-year time series data (1988-2004) of China's tourism economy was used to test the hypothesized model.

\section{Data analysis and model test}

The Ordinary least squares (OLS) method was used to test the relationship between China's tourism GDP (Y) and tourism employment (E). The model is expressed as follows:

$$
Y=\alpha_{0}+\alpha_{1} E+\mu .
$$


Table 1. Data on China's tourism employment and its determining factors.

\begin{tabular}{lccccc} 
Year & $\begin{array}{c}\text { Direct tourism } \\
\text { employment } \\
(\boldsymbol{E})\end{array}$ & $\begin{array}{c}\text { GDP of } \\
\text { tourism } \\
\text { industry } \\
(10,000)\end{array}$ & $\begin{array}{c}\text { Increased } \\
\text { original fixed } \\
\text { assets of } \\
\text { tmillion RMB) }\end{array}$ & $\begin{array}{c}\text { Tourism } \\
\text { employment } \\
\text { (billion RMB) } \\
\text { multiplier }\end{array}$ & $\begin{array}{c}\text { Domestic } \\
\text { tourists } \\
(\boldsymbol{D})\end{array}$ \\
1988 & $10,315.90$ & 31.78 & 390.20 & 3.17 & $(\mathbf{R})$ \\
1989 & $11,503.50$ & 36.74 & 429.36 & 3.35 & 22,200 \\
1990 & $11,653.80$ & 43.26 & 466.20 & 2.93 & 28,000 \\
1991 & $13,108.70$ & 53.30 & 498.23 & 3.35 & 30,000 \\
1992 & $12,852.70$ & 58.96 & 508.50 & 3.16 & 33,000 \\
1993 & $13,263.30$ & 75.18 & 726.95 & 3.27 & 41,000 \\
1994 & $14,022.20$ & 110.83 & 982.95 & 3.20 & 52,400 \\
1995 & $15,049.50$ & 143.23 & $1,251.67$ & 3.54 & 62,900 \\
1996 & $14,290.70$ & 170.97 & $1,546.50$ & 3.22 & 63,900 \\
1997 & $14,650.50$ & 191.52 & $2,147.90$ & 3.25 & 64,400 \\
1998 & $14,851.70$ & 202.76 & $2,574.20$ & 3.32 & 69,400 \\
1999 & $15,055.20$ & 219.03 & $3,805.50$ & 3.30 & 71,900 \\
2000 & $15,319.60$ & 240.62 & $6,473.62$ & 3.42 & 74,400 \\
2001 & $15,186.50$ & 256.40 & $7,791.91$ & 3.50 & 78,400 \\
2002 & $15,176.20$ & 273.89 & $8,123.36$ & 4.06 & 87,800 \\
2003 & $13,766.30$ & 273.93 & $8,439.22$ & 4.07 & 87,000 \\
2004 & $14,063.60$ & 312.86 & $8,723.25$ & 4.09 & 92,300 \\
\hline & & & & &
\end{tabular}

Note: *RMB: Chinese Currency - yuan.

Source: China National Tourism Administration, 1988-2004.

First, the augmented Dickey-Fuller (ADF) test was used in order to identify the long-term equilibrium among the technology level ( $T$ ) (we use Increased Original Fixed Assets of Tourism to represent the technology level and the data came from CNTA), the employment correlation degree $(R)$, and the environmental pressure $(D)$. This test was intended to check the stability of the regression series. To eliminate the effect of serial correlation, and to examine the elasticity of the dependent variable, the method of third maximum lag period test was used without considering any intercept terms or asymptotic terms in the equation. The result showed that the original series and the first order difference series were not stationary. Therefore, the method of ADF was used again to test the second order difference of the original series (Table 2).

In order to find the long-term relationship of the variables under non cointegrated relation, the Vector Auto-Regression (VAR) model was used to screen the variables and the variables of the lag period. It should be noted that all the variables are endogenous, the constants are exogenous and the endogenous variables are of the lag two periods. The VAR Model is expressed as follows:

$$
\ln E=\beta_{0}+\beta_{1} \ln E(-1)+\beta_{2} \ln T+\beta_{3} \ln R+\beta_{4} \ln D+\beta_{5} \ln R(-1)+\beta_{6} \ln T(-2)+\mu,
$$

where $E$ is Direct Tourism Employment; $T$ is Increased Original Fixed Assets of Tourism and $R$ represents Tourism Employment Multiplier; $D$ stands for Domestic Tourists. As the data is in the form of time series, $R(-1)$ means a 
Table 2. ADF test of the regression variables.

\begin{tabular}{lcccc} 
Variables & ADF & Significance level & Critical value & Durbin-Watson test value \\
& & & & \\
$\mathrm{LnE}$ & -2.353533 & $5 \%$ & -1.9755 & 1.851420 \\
$\mathrm{LnT}$ & -1.613934 & $5 \%$ & -1.9755 & 2.017162 \\
$\mathrm{LnR}$ & -2.099728 & $5 \%$ & -1.9755 & 1.968425 \\
$\ln \mathrm{D}$ & -0.969258 & $5 \%$ & -1.9755 & 1.991623 \\
\hline
\end{tabular}

Table 3. OLS regression between tourism GDP $(Y)$ and tourism employment $(E)$.

\begin{tabular}{lcccc}
\hline Explanatory variable & Coefficient & Standard deviation & t -value & Probability \\
Constant & -532.93 & 147.421 & -3.61505 & 0.0025 \\
Employment & 0.0502 & 0.01064 & 4.715987 & 0.0003 \\
\hline
\end{tabular}

Note: * explained variable is $\mathrm{Y}$.

1-term lag of $R$ and $T(-2)$ means a 2-term lag of $T$; and $\mu$ is the statistic error. ADF was used to test if the proposed model fits the actual situation by checking the stability of the regression series. And the VAR model was set up to examine the relationship between tourism employment and its determinants.

\section{Findings and discussion}

\section{Relationship between tourism economy and tourism employment in China}

The OLS result of the relationship between China's tourism GDP $(Y)$ and tourism employment $(E)$ is presented in Table 3.

A regression equation was generated from the analysis as follows:

$$
Y=-532.936+0.0502 E
$$

Figure 1 shows the fitting relationship. The residuals are basically stable, and the level of the fitness is acceptable. The regression result indicates that China's tourism industry employment is positively correlated with the tourism economy. However, the Granger Test shows no causality relationship but a relativity relationship between the two (see Table 4). This means that development of tourism employment is not directly caused by the growth of the tourism economy, even though a positive relationship between them is demonstrated.

\section{Tourism employment growth and its determinants}

The long-term equilibrium among the technology level (T), employment correlation degree $(R)$, and environmental pressure $(D)$ was estimated through the VAR model. The results are shown in Table 5. 


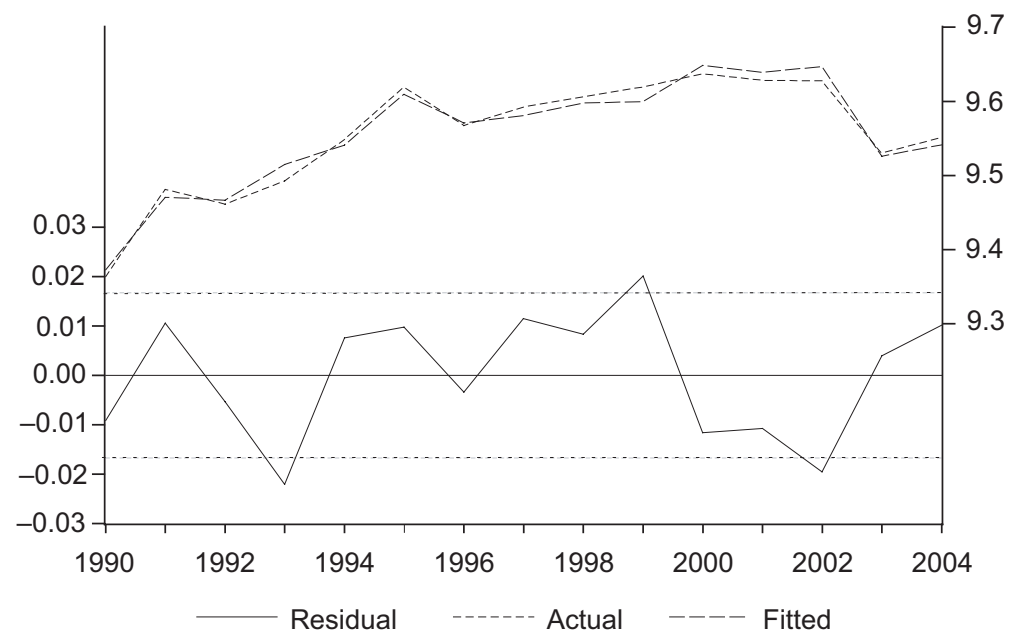

Figure 1. Degree of fit and residual variation.

Table 4. Granger Test of tourism GDP (Y) and tourism employment $(\boldsymbol{E})$.

\begin{tabular}{lcc}
\hline Null hypothesis & F & Probability value \\
$E$ is $Y$ 's Granger cause & 1.47874 & 0.27378 \\
$E$ is not Y's Granger cause & 1.27829 & 0.32036 \\
\hline
\end{tabular}

Table 5. The VAR model estimation.

$\ln E(-1) \quad \ln E(-2) \quad \ln R(-1) \quad \ln R(-2) \quad \ln T(-1) \quad \ln T(-2) \quad \ln D(-1) \quad \ln D(-2)$

\begin{tabular}{lllllllll}
$\mathrm{b}$ & 0.99682 & -0.313248 & -0.547919 & 0.42913 & 0.088930 & -0.078958 & -0.021593 & 0.02162 \\
$\mathrm{SE}$ & 0.462 & 0.40540 & 0.18359 & 0.330 & 0.06249 & 0.06637 & 0.02320 & 0.019 \\
$\mathrm{t}$ & $2.16^{*}$ & -0.77 & $-2.98^{*}$ & 1.30 & 1.42 & -1.19 & -0.93 & 1.12 \\
\hline
\end{tabular}

Note: * Significant at $5 \%$ level.

Table 6. OSL estimation of the VAR model's residual variables.

\begin{tabular}{lcccc}
\hline Variables & Coefficient & Standard error & t-value & p-value \\
Constant & 4.163994 & 0.857429 & 4.856371 & 0.0013 \\
$\ln E 1$ & 0.523674 & 0.094769 & 5.525822 & 0.0006 \\
$\ln T$ & 0.076175 & 0.030636 & 2.486457 & 0.0377 \\
$\ln R$ & 0.387755 & 0.102652 & 3.777367 & 0.0054 \\
$\ln D$ & 0.027960 & 0.008907 & 3.138943 & 0.0138 \\
$\ln R(-1)$ & -0.299634 & 0.098286 & -3.048599 & 0.0159 \\
$\ln T(-2)$ & -0.083293 & 0.034987 & -2.380704 & 0.0445 \\
\hline
\end{tabular}


The results indicate that $\ln E(-2), \ln R(-2), \ln T(-1), \ln T(-2), \ln N D(-1)$ and $\ln D(-2)$ are not significant at $p \leq 0.05$, and should be eliminated from the model. The VAR model is an autoregressive (AR) model based on the OLS method. The above results show that the lag variable and the residual variable are correlated. Therefore, we estimated the residual variables using the OLS method (Table 6). After this residual variable adjustment, the VRA model's $R^{2}$ increased to $95.4 \%$, and the value of Dubbin-Watson test reached 1.8; Akaike Information Criterion (AIC) and Schwarz Information Criterion (SIC) were all satisfactory. These changes indicate that the model fitness is good and the residual test is fine (see Figure 1).

Thus, the short-term equation of tourism employment can be obtained from the VAR results:

$$
\begin{aligned}
& \ln E=4.163994094+0.5236744688 \ln E(-1)+0.07617515967 \ln T+ \\
& 0.3877548695 \ln R+0.02795982782 \ln D-0.2996339239 \ln R(-1) \\
& -0.083293217 \ln T(-2)
\end{aligned}
$$

Given that tourism employment is stable long term, or in other words, suppose $\ln E(-1)=\ln E, \ln R(-1)=\ln R$ and $\ln T(-2)=\ln T$ in the long run, a long-term equilibrium equation of tourism employment can be generated from the above equation as follows:

$$
\ln E=8.7424-0.0149 \ln T+0.1852 \ln R+0.05879 \ln D
$$

Thus, three conclusions can be derived from Equation (4).

First, Equation (6) supports Proposition 1; that is, increased environmental pressure in tourism can enhance tourism employment. According to the results of the regression equation, the elasticity of environment pressure is 0.05 , which means if domestic tourist arrivals increase by $1 \%$, tourism employment would increase by $0.05 \%$.

Second, the advancement of tourism technology has a slightly negative impact on tourism employment growth. The elasticity of technology to tourism employment is -0.0149 . This finding shows that Proposition 2 is not supported by the data. It also means that the 'creative destruction' effect exists in China's tourism industry, as technology can replace manpower. This may also suggest that technology advancement in China's tourism industry lacks essential innovative and industry-specific features, as the job-creation effect of new technology in tourism may have been offset by the 'creative destruction' effect.

Third, the growth of China's tourism employment is driven by the employment multiplier among industries related to tourism. According to Equation (6), every $1 \%$ of increment in the Tourism Employment Multiplier would lead to about $0.19 \%$ increase in the tourism employment. This factor proves to be the most influential and important factor among the three determinant in our model.

Results of this study reveal that tourism in China is an industry with a high employment integrity capacity and is closely related to other industries. Tourism creates a large complementary employment effect on many other 
industries ranging from food production, real estate, and household appliances to education. Therefore, considering the relationship between $\ln E$ and $\ln R$ in Equation (6) and Equation (5), we argue that Proposition 3 is supported from the study.

\section{Conclusion}

On the basis of classical labour economics theory, this study examined the relationship between tourism economy and tourism employment, and investigated decisive factors of tourism employment in China. A model was developed and tested using a 17-year time series dataset. Three propositions regarding the relationships among tourism economy, tourism employment, and environmental pressure were tested.

The results show that tourism technology level, employment correlation between the tourism industry and its related industries, and the environmental pressure caused by tourist arrivals are major determinants of tourism employment growth in China. The study also tested the validity of the proposed model from both short-term and long-term perspectives. These results show that tourism employment in China is driven mainly by tourism's strong capability to push other related industries. China's tourism employment grows accordingly with its tourism economy scale. However, there is no causal relationship between tourism economy and tourism employment. Moreover, the study demonstrates that technology has a weak, negative effect on China's tourism employment.

China is known for its massive land and abundant tourism resources. The growing travel demands from both domestic and international travellers have provided new opportunities for the growth of China's tourism industry. Seeing potential benefits from tourism, the Chinese government has also given great support to the 'Speed up the Development of Tourism Industry' programme and has recognized tourism as one of China's 'strategic' industries (Xu et al, 2009). On the other hand, as suggested by this study, although increased tourist arrival has triggered tourism employment growth, it also has caused great environmental pressure to the natural environment and tourism resources. The implication of this finding is that the Chinese government should take proactive action in order to protect invaluable tourism resources and the environment. We are glad to see that the Chinese government has begun to promote low carbon environmental tourism by advocating the idea of ecological tourism and green environmental protection (Lew, 2001). In the eco-tourism sector, travel agencies and tour guides have also started to encourage visitors to walk to the core scenic area rather than taking vehicles. This implies that both the government and the industry are more environmentally conscious.

The study found that tourism multiplier plays an important role in driving China's tourism employment. The development of the tourism industry is highly integrated with related industries, and can directly drive the development of food service, transport, accommodation, financial service, insurance and other service industries. It can also indirectly influence infrastructure, urban construction, agriculture and cultural development. Therefore, tourism development can create many employment opportunities in those industries. 
The implication is to maximize the tourism industry's capacity in absorbing labor surplus, by encouraging cooperation between tourism and its related industries. For example, Fu yang, a famous tourism destination in Anhui province, has stepped forward in this direction. The local government has realized tourism's multiplier impacts in driving the development of related industries and has set up funding to support the cooperation between tourism and its related industries (Chen, 2012).

The study also suggests that the 'creative destruction' effect exists in China's tourism industry. Consequently, the job-creation effect of new technology in tourism has been offset by the 'creative destruction' effect of technology. The implication is that innovations in tourism technology should be encouraged so that the 'creative destruction' effect may be eliminated, or at least mitigated. Thus, more employment opportunities could be created as China's tourism industry advances.

\section{References}

Aghion, P., and Howitt, P. (1994), 'Growth and unemployment', Review of Economic Studies, Vol 61, No 3, pp 477-494.

Akkemik, K.A. (2012), 'Assessing the importance of international tourism for the Turkish economy: a social accounting matrix analysis', Tourism Management, Vol 33, No 4, pp 790-801.

Ashworth, J., and Thomas, B. (1999), 'Patterns of seasonality in employment in tourism in the UK', Applied Economics Letters, Vol 6, No 11, pp 735-740.

Balaguer, J., and Cantavella-Jorda, M. (2002), 'Tourism as a long-run economic growth factor: the Spanish case', Applied Economics, Vol 34, No 7, pp 877-884.

Brenner, L., and Aguilar, A.G. (2002), 'Luxury tourism and regional economic development in Mexico', The Professional Geographer, Vol 54, No 4, pp 500-520.

Chang, J. (2005), 'The employment elasticity in the process of economy growth of China: affecting factors and employment evaluation', Study of Finance and Economics, Vol 5, pp 29-30.

Chen, X. (2012), 'Speed up the construction of new formats tourism projects and achieve Fuyang tourism "breakthrough"' (http://www.ysnews.org/article/201202/120921.htm, accessed 12 August 2013).

Chetri, P., Corcoran, J., and Hall, C.M. (2008), 'Modeling the patterns and drivers of tourism related employment for South-East Queensland, Australia - a spatial econometric approach', Tourism Recreation Research, Vol 33, No 2, pp 25-38.

China National Tourism Administration (2007), 'The state council document number forty-first on the promotion of tourism' (http://www.gov.cn/zwgk/2009-12/03/content_1479523.htm, accessed 12 August 2013).

CHINA POPIN (2009), 'Influence of China's future demographic trends on employment (abstract)' (http://www.cpdrc.org.cn/yjwx/yjwx_detail.asp?id=3159, accessed 16 January 2009).

Falk, L.H., and Broner, A. (1980), 'Specialization in service industry employment as a state policy', Growth \& Change, Vol 11, No 4, pp 18-23.

Fayissa, B., Nsiah, C., and Tadasse, B. (2008), 'Impact of tourism on economic growth and development in Africa', Tourism Economics, Vol 14, No 4, pp 807-818.

Fayissa, B., Nsiah, C., and Tadesse, B. (2009), 'Tourism and economic growth in Latin American countries (LAC)', Middle Tennessee State University, Department of Economics and Finance, working paper no. 2009-02.

Gamble, P.R. (1988), 'Tourism technology: developing effective computer systems', Tourism Management, Vol 9, No 4, pp 317-325.

Hall, R.E., and Lilien, D.M. (1979), 'Efficient wage bargains under uncertain supply and demand', The American Economic Review, Vol 69, No 5, pp 868-879.

Holloway, J.C. (1994), The Business of Tourism, Addison-Wesley Longman, Harlow.

Huybers, T., and Bennett, J. (2000), 'Impact of the environment on holiday destination choices of prospective UK tourists: implications for tropical North Queensland', Tourism Economics, Vol 6 No 1, pp 21-46. 
Ireland, M. (1993), 'Gender and class relations in tourism employment', Annals of Tourism Research, Vol 20, No 4, pp 666-684.

Johnson, P., and Thomas, B. (1990), 'Employment in tourism: a review', Industrial Relations Journal, Vol 21, No 1, pp 36-48.

Joppe, M. (2012), 'Migrant workers: challenges and opportunities in addressing tourism labor shortage', Tourism Management, Vol 33, No 3, pp 662-671.

Lew, A.A. (2001), 'Tourism development in China: the dilemma of bureaucratic decentralization and economic liberalization', in Harrison, D., ed, Tourism in the Less Developed World, 2nd edn, CAB International, Wallingford, pp 109-136.

Li, J.F., and Li, M.Y. (1999), 'On the calculation of tourism industry and tourist adding value', Tourism Tribune, Vol 5, pp 16-20.

McClary, S. (2002), 'Growth in tourism grinds to a halt', Caterer E Hotelkeeper, Vol 191, No 4209, p 8.

Nwanna, G.I. (1996), 'Currency devaluation and growth: the case of tourism-dependent economy', International Economics, Vol 49, No 2, pp 261-273.

Oh, C.O. (2005), 'The contribution of tourism development on economic growth in the Korean economy', Tourism Management, Vol 26, No 1, pp 39-44.

Pissarides, C.A. (1990), Equilibrium Unemployment Theory, MIT Press, Cambridge, MA.

Pomeroy, R.S., Uysal, M., and Lamberte, A. (1988), 'An input-output analysis of South Carolina's economy: with special reference to coastal tourism and recreation', Leisure Sciences, Vol 10, No 4, pp 281-288.

Poon, A. (1993), Tourism, Technology and Competitive Strategies, CAB International, Wallingford.

Reime, M., and Hawkins, C. (1979), 'Tourism development: a model for growth', Cornell Hotel and Restaurant Administration Quarterly, Vol 20, pp 67-74.

Romer, P.M. (1986), 'Increasing returns and long run growth', Journal of Political Economy, Vol 94, No 5, pp 1002-1037.

Rong, M. (2003), Chinese Employment Report 2002, Labor and Social Security Press, Beijing.

Ross, G.F. (1992), 'Resident perceptions of the impact of tourism on an Australian city', Journal of Travel Research, Vol 30, No 3, pp 13-17.

Saint-Paul, G. (1992), 'Technological choice, financial markets and economic development', European Economic Review, Vol 36, No 4, pp 763-781.

Schumpeter, J.A. (1934), The Theory of Economic Development, Harvard University Press, Cambridge, MA.

Simpson, F. (1999), 'Tourist impact in the historic centre of Prague: resident and visitor perceptions of the historic built environment', Geographical Journal, Vol 165, No 2, pp 173-183.

Sinclair, M.T. (1998), 'Tourism and economic development: a survey', Journal of Development Studies, Vol 34, No 5, pp 1-51.

Strizzi, M., and Meis, S. (2001), 'Challenges facing tourism markets in Latin America and the Caribbean region in the new millennium', Journal of Travel Research, Vol 40, No 2, pp 183-192.

UNWTO (2001), 'Tourism vision 2020: East Asia and Pacific' (http://media.unwto.org/en/pressrelease/2011-06-22/unwto-executive-council-endorses-efforts-better-position-tourism-global-age).

Wanhill, S.R.C. (1988), 'Tourism multipliers under capacity constraints', The Service Industries Journal, Vol 8, No 2, pp 136-142.

WTTC (2000), 'The economic impact of travel and tourism development in the APEC region' (http://publications.apec.org/publication-detail.php?pub_id=671).

$\mathrm{Xu}$, Z., Zhang, J., and Wall, G. (2009), 'The impact of residents' sense of place on their support for the development of regional tourism', Dili xuebao (Acta Geographica Sinica), Vol 64, pp 736 744 . 


\section{Appendix 1}

\section{Proof of the theoretical model}

The relationship between environmental pressure, $\zeta$, resulting from tourism development and the per-capita output of tourism, $y$, can be written as follows:

$$
\zeta=y z^{\rho}
$$

Here, $z$ is the influencing degree of the environment pressure caused by tourism production and consumption; $\rho$ is the elasticity of $z$ to $\zeta$.

As production in tourism depends mainly on the use of natural and social environment resources rather than physical capital, which is different from manufacturing industry, the TPF (Total Productivity of Factors) of tourism economy contains not a technical factor but an environmental factor. Then two assumptions can be conducted naturally to simplify our analysis:

Assumption 1: It is appreciate to ignore capital adjustment cost and capital depreciation in tourism production in the present framework.

Assumption 2: Companies in tourism can compete in infinite time and each of them is normalized to possess 1 unit manpower and $x$ units intermediate product stocks.

From Equation (1) and Equation (A1), the tourism production function can be reformulated as follows:

$$
y=A_{t}^{\rho / \alpha+\rho} \zeta^{\alpha / \alpha+\rho} x^{\alpha \rho / \alpha+\rho}=\breve{A}_{t} \varphi(x)
$$

where $\breve{A}_{t}=A_{t}^{\rho / \alpha+\rho} \zeta^{\alpha / \alpha+\rho}$ is the productivity parameter decomposed of technical level and environment pressure; $\varphi(x)=x^{\alpha \rho / \alpha+\rho}$ represents the general production function of intermediate product and environment factors.

The objective the representative company is

$$
\max \left(y-p_{t} x\right)=\breve{A}_{t} \varphi(x)-p_{t} x
$$

Here, $t$ is the time when the company is founded; $p_{t}$ is the price of intermediate product.

'At the steady-state growth path, the price of intermediate product and the productivity will increase at the same equilibrium growth rate' (Aghion and Howitt, 1994). So if the company never changes its technology, the company will lose at a certain time with the rise of $p_{t}$. Then the company will stop production and lay off its employees, and at the same time $p_{t}$ will reach its highest point $\bar{p}$. Let's assume $t_{0}=t+\varepsilon \leq s$ which represents that the time the employees work in the company and then the company will make deficit after time $s$, which will lead to employee lay off and the highest price $\bar{p}=p_{0} e^{g\left(t_{0}+s\right)}$. So, here, $s$ represents the employees' working time.

Under competitive situation, the productivity-adjusted equilibrium condition can be gained from Equation (A3):

$$
\frac{\bar{p}}{\breve{A}_{t}}=\left.\varphi^{\prime}(x)\right|_{p=\bar{p}} \text {. }
$$


Here, $\left.\varphi^{\prime}(x)\right|_{p=p}$ is the marginal output of the semi finished product at the highest price, that is $\left.\varphi^{\prime}(x)\right|_{p=\bar{p}}=M P_{x}^{M}$. When combining $\breve{A}_{t}, A_{t}$ and $\bar{p}$ together, Equation (A4) can be reformulated as:

$$
s=\frac{\Omega}{g},
$$

where:

$$
\Omega=\ln M P_{x}^{M}-\frac{(\alpha+\rho) \ln p_{\varepsilon}+\alpha g t}{\ln A_{0}{ }^{\rho} \zeta^{\alpha}} ; p_{\varepsilon}=p_{0} e^{e^{\varepsilon \varepsilon}} .
$$

It is revealed from Equation (A5) that equilibrium growth rate of the tourism economy is negative to the employees' working periods. In the other words, the tourism economy's growth has a negative effect on tourism employment, because the growth of tourism economy imposes a 'Creative Destruction effect' on tourism employment (Schumpeter, 1934; Saint-Paul, 1991; Caballero, 1993).

Additionally, in the present framework, 'expanding effect of pressure' occurs when environment pressure, $\zeta$, has a positive effect on tourism employment.

When the tourism economy enters a steady state, $v$ keeps constant and the speed of workers losing jobs is approaching to $1-u / s$, where $u$ is the unemployment rate.

At the steady state, when $u$ is at the natural unemployment rate $u^{*}$ (Hall, 1979), the speed of the employed workers losing their jobs equals the speed of the unemployed workers finding the jobs, that is $1-u / s=m(1, v)$. Introducing Equation (A5) into the above function, it yields:

$$
\begin{aligned}
w^{*} & =1-u^{*}=m(1, v) \frac{\Omega}{g} \\
& =m(1, v)\left[\ln M P_{x}^{M}-\frac{(\alpha+\rho) \ln p_{\varepsilon}+\alpha g t}{\ln A_{0} \rho \xi^{\alpha}}\right] / g .
\end{aligned}
$$

Thus, we prove the theoretical model of this paper. 


\section{Appendix 2}

\section{Proof of Proposition 1 and Proposition 2}

\section{Proof for Proposition 1}

In reality, if the work time is positive, then it yields $\Omega>0$. And the conditions of proposition mean that:

$$
w^{*}=m(1, v) \frac{\Omega}{g},
$$

and $m(1, v)$ are constant, so observing Equation (2) reveals that pressure degree $\zeta$ is positive to the growth rate of employment $w^{*}$ given the $m(1, v)$.

\section{Proof for Proposition 2}

Observing Equation (2), we can discover that $M P_{x}^{M}, \alpha, \rho, \rho_{\varepsilon}, g, \zeta$ are constant variables when $m(1, v)$ is given (meaning the effect of 'Creative Destruction' is offset) and $w^{*}$ is in steady state. Thus the increasing of technology $\left(A_{0}\right)$ leads to the increase of employment rate $\left(w^{*}\right)$. 